\title{
Double-difference Relocation of the Aftershocks of the Tecomán, Colima, Mexico Earthquake of 22 January 2003
}

\author{
Vanessa Andrews, ${ }^{1}$ Joann Stock, ${ }^{1}$ Carlos Ariel Ramírez Vázquez, ${ }^{2}$ and Gabriel Reyes-Dávila ${ }^{2}$
}

\begin{abstract}
On 22 January 2003, the $M_{\mathrm{w}}=7.6$ Tecomán earthquake struck offshore of the state of Colima, Mexico, near the diffuse triple junction between the Cocos, Rivera, and North American plates. Three-hundred and fifty aftershocks of the Tecomán earthquake with magnitudes between 2.6 and 5.8, each recorded by at least 7 stations, are relocated using the double difference method. Initial locations are determined using $\mathrm{P}$ and $\mathrm{S}$ readings from the Red Sismológica Telemétrica del Estado de Colima (RESCO) and a 1-D velocity model. Because only eight RESCO stations were operating immediately following the Tecomán earthquake, uncertainties in the initial locations and depths are fairly large, with average uncertainties of $8.0 \mathrm{~km}$ in depth and $1.4 \mathrm{~km}$ in the north-south and east-west directions. Events occurring between 24 January and 31 January were located using not only RESCO phase readings but also additional $\mathrm{P}$ and $\mathrm{S}$ readings from 11 temporary stations. Average uncertainties decrease to $0.8 \mathrm{~km}$ in depth, $0.3 \mathrm{~km}$ in the east-west direction, and $0.7 \mathrm{~km}$ in the north-south direction for events occurring while the temporary stations were deployed. While some preliminary studies of the early aftershocks suggested that they were dominated by shallow events above the plate interface, our results place the majority of aftershocks along the plate interface, for a slab dipping between approximately $20^{\circ}$ and $30^{\circ}$. This is consistent with the slab positions inferred from geodetic studies. We do see some upper plate aftershocks that may correspond to forearc fault zones, and faults inland in the upper plate, particularly among events occurring more than 3 months after the mainshock.
\end{abstract}

Key words: Aftershocks, Colima, earthquakes, seismicity, relocation.

\section{Introduction}

Both the Cocos and Rivera Plates are subducting beneath the North American Plate, with a diffuse

1 California Institute of Technology, 1200 E California Blvd, MC 252-21, Pasadena, CA 91125, USA. E-mail: vandrews@caltech.edu

2 University of Colima, Av. Gonzalo de Sandoval 444, CP. 28045 Colima, Col, Mexico. boundary between them, forming a triple junction near the state of Colima. The Cocos-North America subduction zone has a convergence rate of approximately $37 \mathrm{~mm} /$ year near the triple junction (DeMETs and Wilson, 1997). The rate of Rivera-North America subduction near the triple junction is considered to be less than this, but the exact value, as well as the degree of obliquity, is still debated (see discussion by Kostoglodov and BAndy, 1995). Both of these trench segments are seismically active. In $<80$ years, this region has had five large earthquakes: two in $1932\left(M_{\mathrm{w}}=8.2\right.$ and $\left.M_{\mathrm{w}}=7.8\right)$, one in 1973 $\left(M_{\mathrm{w}}=7.6\right)$, one in $1995\left(M_{\mathrm{w}}=8.0\right)$, and the Tecomán earthquake in 2003. The National Earthquake Information Center (NEIC) and Servicio Sismológico Nacional (SSN) reported a magnitude of 7.6 for this event.

Following the 1995 event, two sections of the subduction zone that had not ruptured since 1932 were identified: the Colima Gap, located offshore of the state of Colima, and the Vallarta Gap to the north (YAGI et al., 2004; see Fig. 1). While the Vallarta Gap is clearly still open, it has not been agreed upon whether the 2003 Tecomán earthquake fully ruptured the Colima Gap.

The Tecomán earthquake caused 21 casualties, seven of which were in Colima city, and destroyed 1,065 buildings in Colima city (ZoBin and PizanoSILVA, 2007). It caused significantly more damage in Colima city than in other cities closer to the epicenter, including Tecomán and Manzanillo, causing speculation about the possibility of faulting on multiple planes. Additionally, the presence of a precursory phase degraded the ability to constrain the depth and the fault plane dip, making it difficult to distinguish between an interplate and an intraplate event (GómEZ-GoNZÁLEZ et al., 2010). 


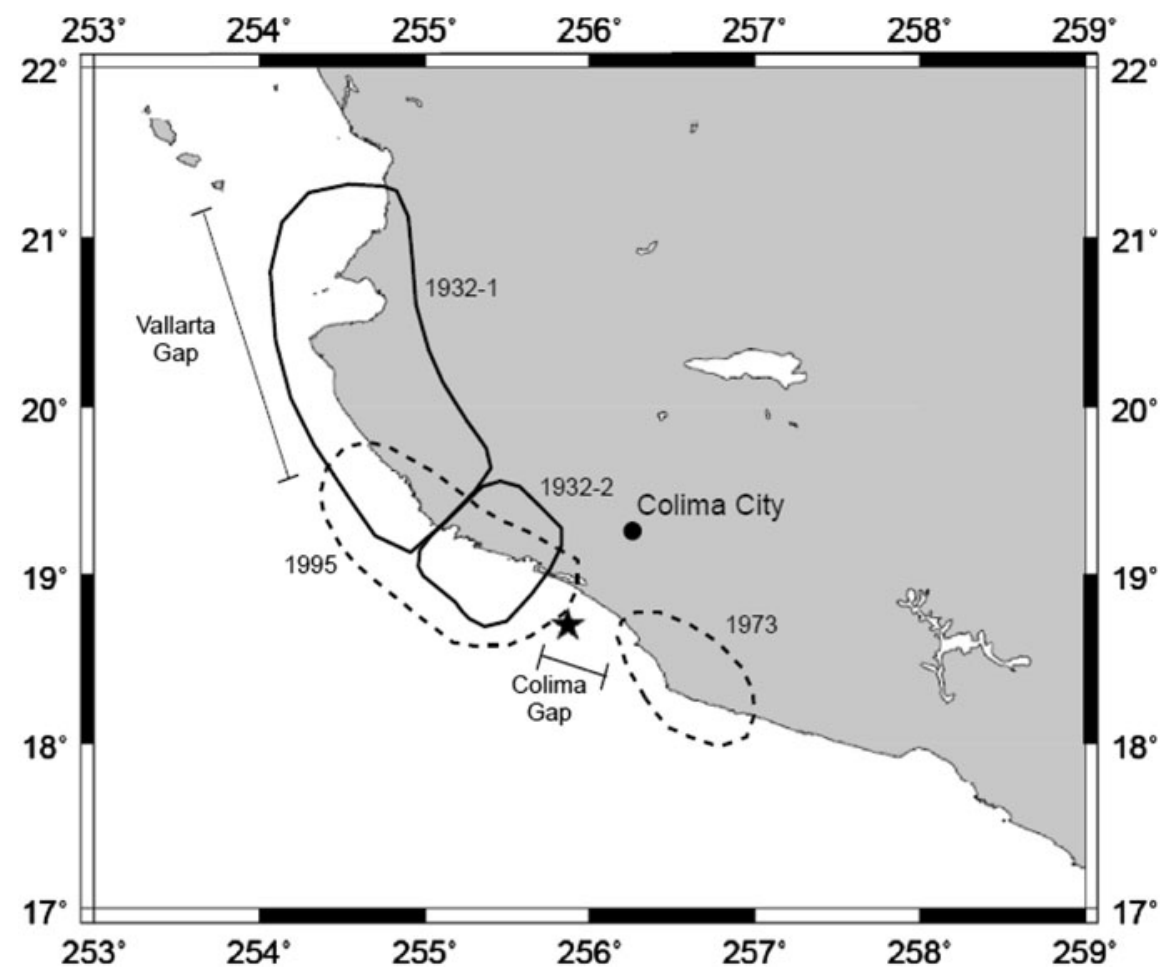

Figure 1

Approximate rupture areas for the 1932, 1973, and 1995 earthquakes, and epicenter for the 2003 earthquake (from YAGI et al., 2004). The 1932 events are shown with a solid line, while the 1973 and 1995 events are shown with a dashed line. The Colima Gap lies between the rupture areas of the 1973 and 1995 events

The University of Colima maintains a network of short-period stations, currently consisting of 12 stations, called the Red Sismológica Telemétrica del Estado de Colima (RESCO), with the primary purpose of monitoring the Colima volcano (Fig. 2). Eleven stations were running during 2003. Amplification is variable from 60 to $120 \mathrm{~dB}$. Analog data are continuously transmitted by radio to the University of Colima, where they are digitized and recorded. All phase-picking is performed manually.

Additionally, after the 2003 mainshock, temporary stations were deployed by various institutions, including the University of Colima, the Centro de Investigación Científica y de Educación Superior de Ensenada (CICESE) and the Universidad Nacional Autónoma de México (UNAM) (Fig. 2).

A preliminary study of the first $72 \mathrm{~h}$ of aftershocks of the Tecomán earthquake, using RESCO data together with data collected by another temporary deployment (University of Guadalajara, not used in this study) suggested that nearly all events occurred in the upper plate (NúÑEZ-CORNú et al., 2004). Consequently, it was concluded that this earthquake was not an interplate event, and therefore it could not have closed the Colima Gap. However, due to a limited number of stations and unfavorable station geometry, errors in locations are large. NúÑEZCoRnú et al., (2004) also assumed that the slab maintained a constant dip from the trench in constraining the interface location. SingH et al., (2003), using data from more regional stations, concluded that the mainshock rupture occurred in the Colima gap; however, their preliminary study was not able to provide details on the aftershock distribution or the geometry of the Wadati-Benioff zone.

In this paper, double difference relocation is used to improve the accuracy of aftershock locations for the months following the earthquake, and to better define the geometry of the Wadati-Benioff zone, using both RESCO data and phase picks from temporary stations. This also allows us to reexamine the importance of the upper plate faulting during the 


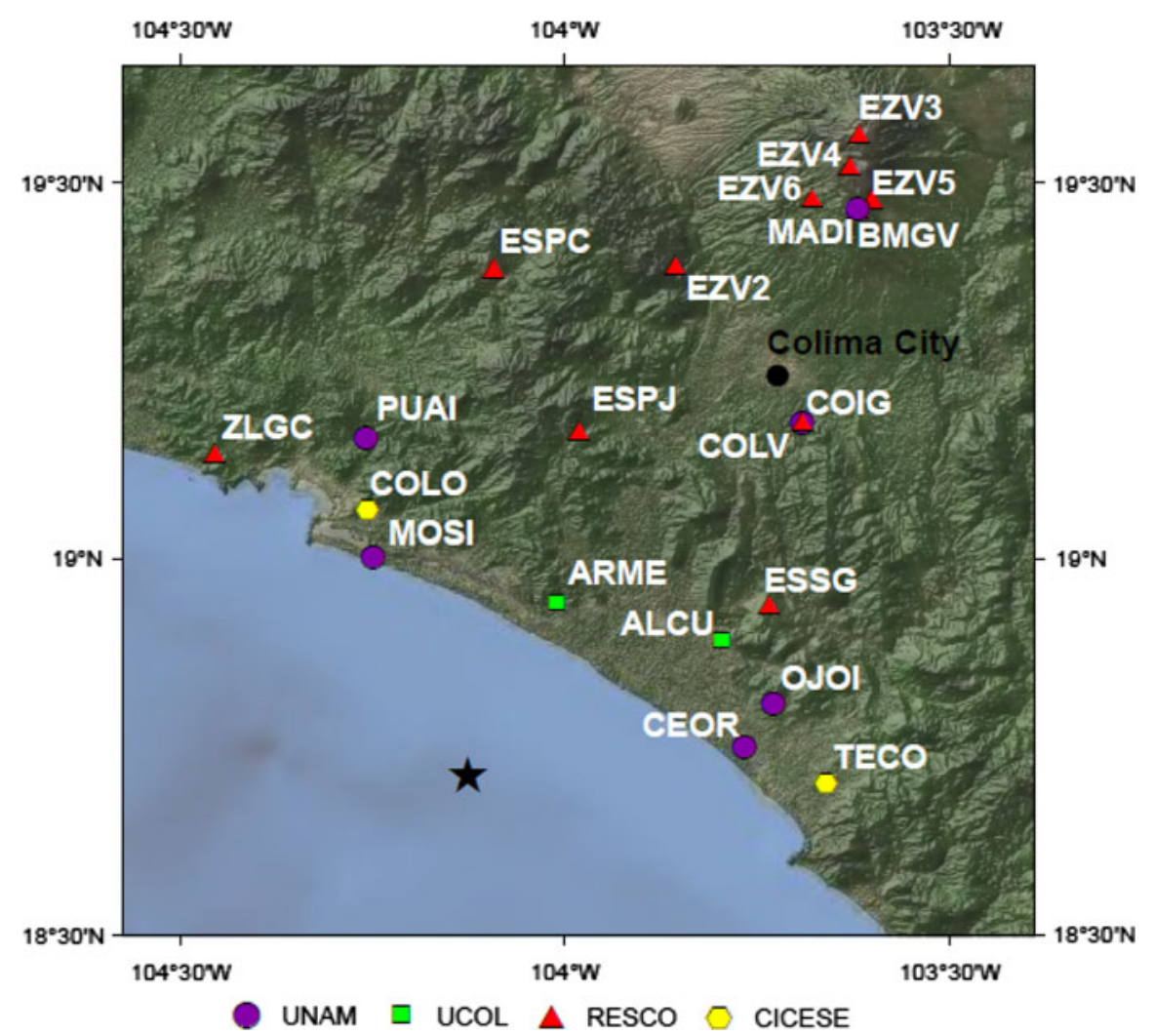

Figure 2

Location of stations used in event relocation. Stations EZV3, EZV4, EZV5, and EZV6 are concentrated near Colima Volcano. Star shows the mainshock epicenter. Topography is from Blue Marble Next Generation (visibleearth.nasa.gov) and ASTER GDEM. ASTER GDEM is a product of METI and NASA

aftershock sequence, and the degree of closure of the Colima Gap.

\section{Data}

Initial event locations were determined using the earthquake location program HYPO71 (LEE and LAHR, 1975), RESCO P and S picks, and a 1D crustal velocity model for the Jalisco block (PACHECO et al., 2003; see Table 1). Of the 2990 events recorded by RESCO between January 22 and December 31, 2003, 617 events were selected for relocation, each of which was recorded by at least seven RESCO stations (Fig. 3a).

Additionally, 219 P-phase picks and 107 S-phase picks were added from 11 temporary stations deployed between 24 January and 31 January. There were 108 events in the time period selected for
Table 1

Velocity model used for determining initial locations (from PACHECO et al., 2003)

\begin{tabular}{ll}
\hline Layer thickness $(\mathrm{km})$ & P-wave velocity $(\mathrm{km} / \mathrm{s})$ \\
\hline 0.4 & 4.60 \\
8.1 & 5.69 \\
10.2 & 6.27 \\
17.3 & 6.71 \\
Half-space & 8.00 \\
\hline
\end{tabular}

relocation, for an average of 3.0 additional phase readings per event. The aperture of the array was increased from $100 \mathrm{~km}$ with only the RESCO stations to a maximum of $130 \mathrm{~km}$ on January 25 and 26, the only days when all 11 of the temporary stations were deployed.

Due to mechanical failures caused by the strong coseismic shaking in Colima, not all of the RESCO stations were able to record the mainshock. 


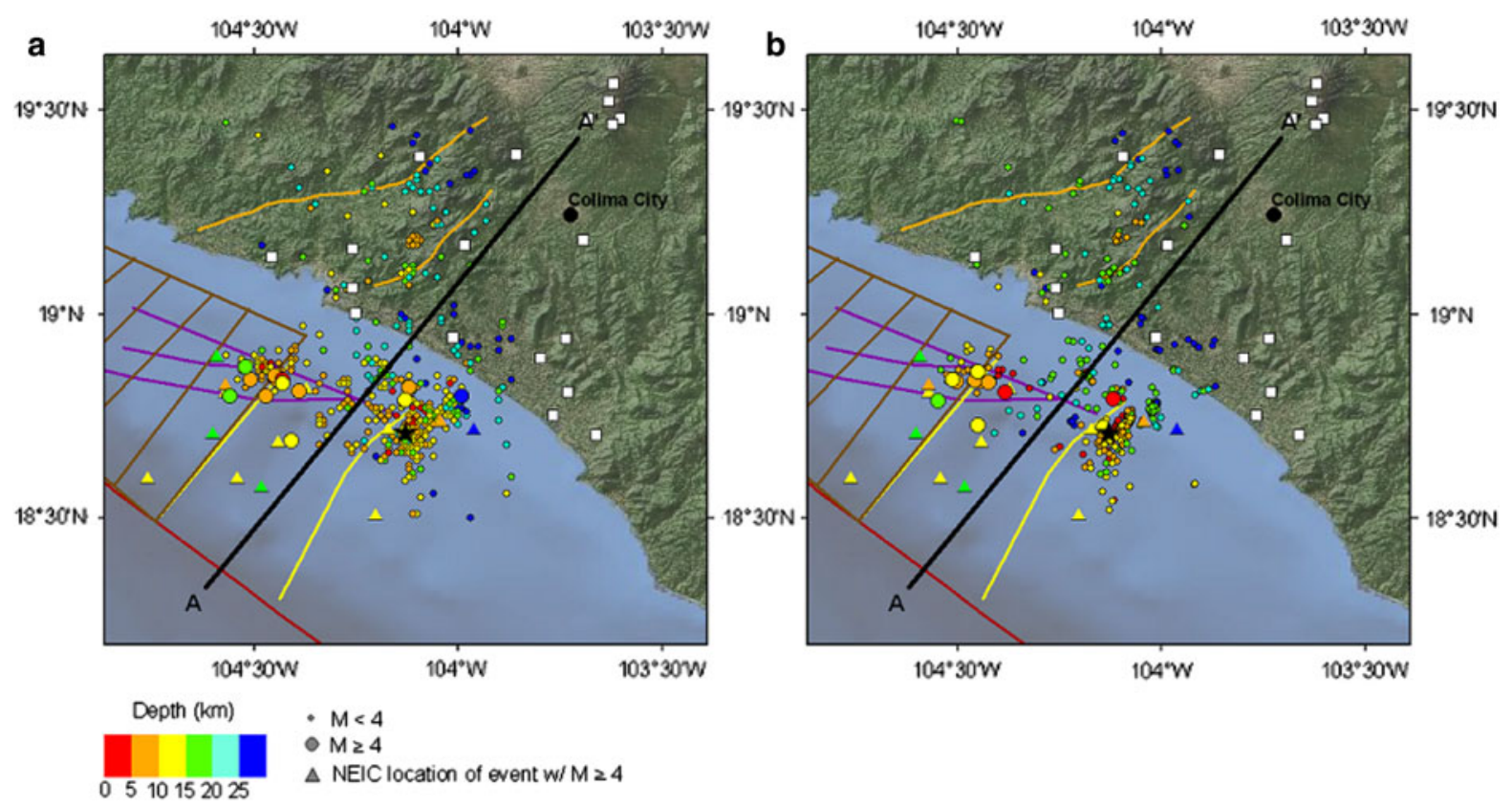

Figure 3

Original event locations (a) and relocations (b), denoted by circles, along with NEIC locations, denoted by triangles. Larger circles represent events with magnitudes $\geq 4.0$, using magnitudes determined by the NEIC, while triangles represent the NEIC locations for those same events. White squares show the station locations. Star shows the mainshock epicenter. $A-A^{\prime}$ line shows the location of Fig. 4. Faults depicted are from BANDY et al., (2005), and include the Tecomán graben (yellow), Middle America trench (red), Tamazula fault zone (orange), and a series of proposed strike-slip faults (purple) and proposed fore-arc sliver moving to the northwest (brown). Topography is from Blue Marble Next Generation (visibleearth.nasa.gov) and ASTER GDEM. ASTER GDEM is a product of METI and NASA

Relocation of the mainshock was not attempted, but rather, the hypocenter used by YAGI et al., (2004) is accepted, at $18.71^{\circ} \mathrm{N}, 104.13^{\circ} \mathrm{W}$, and $20 \mathrm{~km}$ depth. We consider this location to be superior to the NEIC location because of the inclusion of local stations.

Selected events were relocated using the doubledifference method (WALDHAUSER and ElLSwOrTH, 2000) and the progam hypoDD (WALDHAUSER, 2001). The double-difference method uses relative travel times between linked event pairs and iteratively adjusts the locations of the events to minimize the sum of travel-time residuals. While relative locations between events are significantly improved, the centroid of an event cluster is unchanged, so this method will not correct for systematic errors in the absolute location of events.

For fewer than about 100-200 events, depending on computational power, the matrix of travel time differences may be solved using singular value decomposition (SVD), while the matrices from larger sets of events must be solved using a conjugate gradients method (LSQR). The advantage of SVD is that it allows for accurate error computation, whereas LSQR significantly underestimates errors, requiring independent error analysis (WALDHAUSER, 2001). Independent error analysis is beyond the scope of this project; rather, it is assumed that errors for large datasets are comparable to those for subsets of the data.

Focal mechanisms were attempted for offshore and nearshore events; however, the limited aperture of the array prevented us from obtaining well-constrained focal mechanisms for any of these events using first motion polarities and S-P ratios, and techniques using waveform fitting cannot be directly applied to short period data.

\section{Results and Discussion}

Of the 617 events selected for relocation, 350 were relocated by hypoDD, based on several stability criteria discussed by WALDHAUSER and ElLSWORTH 
(2000) (Fig. 3b). The remaining events were discarded. All relocated events had an RMS misfit of $<0.04$ s, which we considered to be an acceptable level of misfit, so no additional events were discarded. Double difference relocation significantly reduces the uncertainties in the location of the events. For the 108 events between 24 January and 31 January, average uncertainties are reduced from 8.0 to $0.8 \mathrm{~km}$ in depth, from 1.4 to $0.3 \mathrm{~km}$ in the east-west direction, and from 1.4 to $0.7 \mathrm{~km}$ in the north-south direction.

For events not in this time frame, only RESCO data are used in the relocation, and uncertainties are computed using a randomly selected subset of 108 events. Average errors are reduced from 6.6 to $1.0 \mathrm{~km}$ in depth, from 1.6 to $0.5 \mathrm{~km}$ in the east-west direction, and from 1.6 to $1.0 \mathrm{~km}$ in the north-south direction. Errors for the entire dataset are probably significantly smaller, evidenced by lower RMS misfits for the entire dataset than for the subset, but, as discussed previously, accurate distance errors are not available for the entire dataset.

In a trench-perpendicular cross-section of the original event locations (Fig. 4c), the locations are too scattered to identify the seismic structure. In a cross-section of the relocated events (Fig. 4d), however, a number of events to the southeast of the line depicted in Fig. 3 appear to define a slab interface dipping between $20^{\circ}$ and $30^{\circ}$. The position and dip of the slab are consistent with those inferred from geodetic studies (Sснмiтt et al., 2007; Hutton et al., 2001). This is one of the main important results from this study, because previous studies of the seismicity (e.g., PARdo and SuÁrez, 1995; NúÑEZ-Cornú et al., 2004) have differed in their interpretations of the dip of the shallow part of the Wadati-Benioff zone in this region, with dips varying from $12^{\circ}$ to $48^{\circ}$. Other recent studies (YANG et al., 2009) have left the question open.

However, for events to the northwest of this line, which marks the approximate boundary between the Cocos and Rivera plates, the interface appears to dip much more shallowly, at least at depths shallower than $30 \mathrm{~km}$. This is unexpected, as it is generally agreed that the Rivera Plate dips more steeply than the Cocos Plate at depths $>40 \mathrm{~km}$ (PARDO and SuÁREZ, 1995; YANG et al., 2009). However, previous studies did not have much resolution on the shallower part of the plate interface. The geometry we observe is consistent with the Rivera plate having a more shallowly dipping seismogenic zone than the Cocos plate, with possibly a smaller radius of curvature before it bends down to have a steeper dip than the Cocos plate at depths below the seismogenic zone. This smaller radius of curvature may be related to the high, rugged topography of the Jalisco block, although more investigation, particularly geodynamic modeling, would be necessary to confirm this relationship.

In constructing a geodetic slip model for the 1995 Colima-Jalisco earthquake, which ruptured to the northwest of the Tecomán earthquake, HutTon et al., (2001) found a best-fit dip of $9^{\circ}$ down to a depth of $40 \mathrm{~km}$, at which point the dip increased to $25^{\circ}$. This dip is consistent with that indicated by the seismicity, although the seismicity suggests that the increase in dip to $25^{\circ}$ may start sooner, at approximately $20 \mathrm{~km}$ (Fig. 4d).

Our results do not support the hypothesis of NúÑEZ-CoRnú et al., (2010) that rupture on the plate interface did not begin until at least $72 \mathrm{~h}$ after the mainshock. Our relocations show many events near the slab interface starting on January 22, with no detectable difference in event distribution before and after the first $72 \mathrm{~h}$.

While a large number of the events appear to occur on or near the slab interface, there are two additional clusters of events that are clearly located above the interface. The cluster of onshore events (Fig. 4b) is located near the Tamazula fault zone (GARDuÑo-Monroy et al., 1998) and most of the events in this cluster occurred more than 3 months after the mainshock, suggesting that these events may be unrelated to the mainshock. The cluster of offshore events trending subhorizontally at distances of 45-75 km from the trench appears to indicate additional crustal faulting in the North American plate. These events occurred near the NW side of the Manzanillo trough/El Gordo graben (Fig. 3) in a region of the forearc characterized by NE-striking normal faults and trench-parallel strike-slip faults (BANDY et al., 2005). More research is necessary to determine which of these upper plate faults slipped in these aftershocks. 

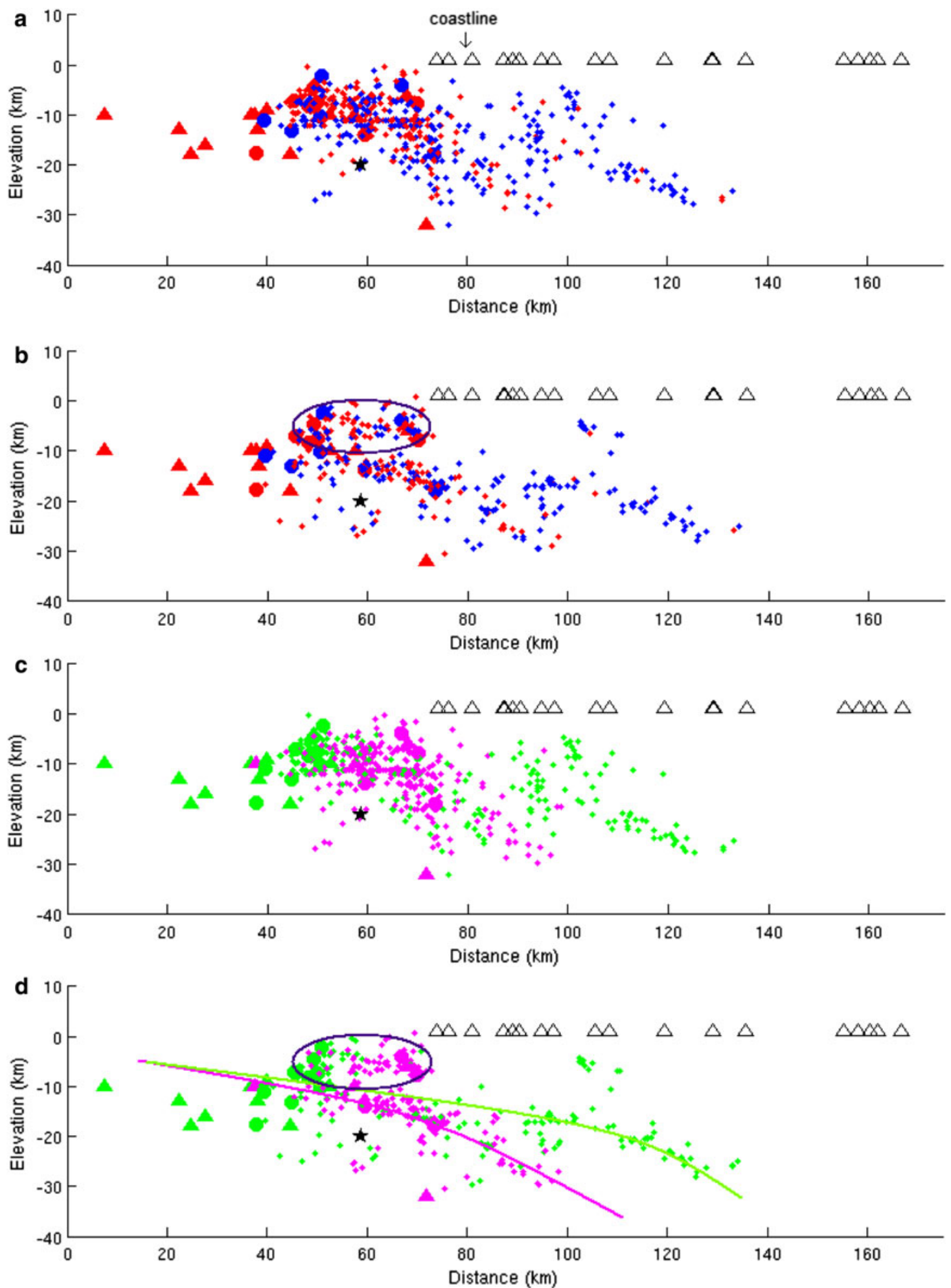

Within 72 hours of mainshock

Northwest of cross-section line

More than 72 hours after mainshock

Southeast of cross-section line 
Figure 4

Cross-sections from A-A' (Fig. 3) of original event locations (a, b) and relocations (c, d), denoted by circles, along with NEIC locations, denoted by triangles. All events shown in Fig. 3 are included, with a maximum distance of events from the projection line of $78 \mathrm{~km}$. Larger circles represent events with magnitudes $\geq 4.0$, as determined by the NEIC, while triangles represent the NEIC locations for those same events. In parts $\mathbf{a}, \mathbf{b}$, red symbols represent events that occurred within $72 \mathrm{~h}$ of the mainshock, while blue symbols represent events that occurred more than $72 \mathrm{~h}$ after the mainshock. In parts $\mathbf{c}, \mathbf{d}$, green symbols represent events to the northwest of the cross-section shown in Fig. 3, while magenta symbols represent events to the southeast. Star shows the mainshock epicenter. Magenta and green curves show an approximate fit to the subduction interface for the Cocos and Rivera Plates, respectively. Purple ellipse outlines the shallow event cluster discussed in the text. Black triangles show the projection of the seismic stations. Distances are relative to the trench. The coastline marked in part a is shown where it intersects the line shown in Fig. 3; some stations appear to be offshore because the coastline is not perpendicular to this line. While there are numerous small events beneath the Colima Volcano, these events were excluded from this study because they were not recorded by a sufficient number of stations

Some of the events in this cluster have depths $<1 \mathrm{~km}$, which is physically unreasonable, particularly for offshore events. Most of these events have only RESCO station readings, suggesting that the locations might be adversely affected by the unfavorable geometry of the RESCO stations. However, comparisons of subsets of the data relocated with and without phase readings from temporary stations show that while the addition of these stations moves outlying events closer to neighboring events, they are not moved in a consistent direction. The most likely explanation for these depth errors is that the velocity model does not adequately match the shallow velocity structure for shallow events.

The mainshock appears to be slightly below most of the aftershocks. As mentioned previously, the mainshock was not included in the relocation; thus the accuracy of the relative location of the mainshock to the aftershocks cannot be determined, and should not be too highly interpreted.

We now consider an additional set of locations, those determined by the NEIC using teleseismic data. A comparison of RESCO locations to those determined by the NEIC shows that RESCO locations are generally located inland of NEIC locations (Figs. 3, 4). This is unsurprising, as a catalog search of events in this region shows that the NEIC locations are typically further offshore than would be predicted from the location of the plate boundary, suggesting inaccuracies in the NEIC velocity model. As the centroid of the events is essentially unchanged by relocation, relocating the events does not change this trend.

The large number of events on or near the slab interface indicates that the Tecomán earthquake did break the Colima Gap. Thus, one might conclude that the Vallarta Gap would be the most likely location for the next earthquake on this system to occur, assuming that the northwestward decrease in convergence rate along the trench is not a significant factor. There is one caveat to this conclusion, however. The 2003 aftershock distribution shows a sparsity of events in the Tecomán graben (Fig. 3) which could indicate that there may still be a small gap remaining between the 2003 Tecomán earthquake sequence and the more poorly known extent of the 1973 earthquake sequence to the southeast.

\section{Conclusions}

The double-difference relocations of seismicity for 11 months following the January 22, 2003 earthquake illustrates the following important characteristics of the Middle America trench subduction system in the region offshore of the state of Colima, Mexico. (1) The aftershocks define a Wadati-Benioff zone with a dip of $20^{\circ}-30^{\circ}$, indicating slip on the main plate interface beneath the North America plate. (2) Aftershocks in this location are present throughout the aftershock sequence, consistent with a model in which the mainshock also ruptured the main plate interface. (3) A difference in dip of the seismogenic zone is detected on either side of the Tecomán graben, with the plate on the NW side dipping more shallowly. This suggests that the Rivera plate dips more shallowly than the Cocos Plate, at least for depths $<30 \mathrm{~km}$. This may imply a difference in the radius of curvature of the two plates as they descend into the mantle. (4) A significant number of aftershocks occurred on the Rivera-North American plate interface. (5) Clusters of shallow events that occurred off of the main subduction interface, within this time frame, are attributed to (a) active submarine 
strike-slip or normal faults in the forearc of the Middle America Trench and (b) the onshore Tamazula fault zone. (6) The Colima Gap was at least partly closed, and may have been entirely closed, by the 2003 earthquake sequence.

\section{Acknowledgments}

Research supported by the US National Science Foundation under grant EAR-0510395 and by the California Institute of Technology's division of Geological and Planetary Sciences under contribution 10051.

Open Access This article is distributed under the terms of the Creative Commons Attribution Noncommercial License which permits any noncommercial use, distribution, and reproduction in any medium, provided the original author(s) and source are credited.

\section{REFERENCES}

Bandy, W. L., Michaud, F., Bourgois, J., Calmus, T., Dyment, J., Mortera-Gutierrez, C. A., Ortega-Ramírez, J., Pontoise, B., Royer, J.-Y., Sichler, B., Sosson, M., Rebolledo-Vieyra, M., Bigot-Cormier, F., Díaz-Molina, O., Hurtado-Artunduaga, A. D., Pardo-Castro, G., and Troulllard-Perrot C. (2005), Subsidence and Strike-Slip Tectonism of the Upper Continental Slope off Manzanillo, Mexico, Tectonophysics 398, 115-140.

DeMets, C., and Wilson, D. S. (1997), Relative Motions of the Pacific, Rivera, North American, and Cocos Plates Since 0.78 Ma, J. Geophys. Res., 102 (B2), 2789-2806.

Garduño-Monroy, V., H., SAucedo-Girón, R., JiméneZ, Z., Gavilanes-Ruiz, J. C., Cortes-Cortes, A., and Uribe-Cifuentes, R. M. (1998), La Falla Tamazula, Límite Suroriental del Bloque Jalisco, y sus Relaciones con el Complejo Volcánico de Colima, Mexico, Rev. Mex. Ciencias Geológicas 15, 132-144.

Gómez-González, J. M., Mendoza, C., Sladen, A., and GuzmánSpeziale, M. (2010), Kinematic Source Analysis of the 2003 Tecomán, México, Earthquake (Mw 7.6) using Teleseismic Body Waves, Bol. Soc. Geol. Mex. 62, 249-262.

Hutton, W., DeMets, C., Sánchez, O., Suárez, G., and Stock, J. (2001), Slip Kinematics and Dynamics During and After the 1995 October $9 M_{w}=8.0$ Colima-Jalisco Earthquake, Mexico, from GPS Geodetic Constraints, Geophys. J. Int. 146, 637-658.

Kostoglodov, V. and Bandy, W. (1995), Seismotectonic Constraints on the Convergence Rate between the Rivera and North America Plates, J. Geophys. Res. 100 (B9), 17977-17989.
LeE, W. H. K. and Lahr, J. C. (1975), HYPO71 (Revised): A Computer Program for Determining Hypocenter, Magnitude, and First Motion Pattern of Local Earthquakes, U.S. Geol. Surv. Open File Rept. 75-311.

Núñez-Cornú, F. J., Reyes-Dávila, G. A., Rutz López, M., Trejo Gómez, E., Camarena-García, M. A., and Ramírez-VAzquez, C. A. (2004), The 2003 Armería, México Earthquake (M $M_{w}$ 7.4): Mainshock and Early Aftershocks, Seism. Res. Lett. 75, 734-743.

NúÑez-Cornú, F. J., Rutz-López, M., Márquez-Ramírez, V., Suárez-Plascencia, C., and Trejo Gómez, E. (2010), Using an Enhanced Dataset for Reassessing the Source Region of the 2003 Armería, Mexico Earthquake, Pure Appl. Geophys., doi: 10.1007/s00024-010-0178-x

Pacheco, J. F., Bandy, W., Reyes-Dávila, G. A., NúÑez-Cornú, F. J., Ramírez-VÁzquez, C. A., and Barrón, J. R. (2003), The Colima, Mexico, Earthquake ( $M_{w}$ 5.3) of 7 March 2000: Seismic Activity Along the Southern Colima Rift, Bull. Seism. Soc. Am. 93, 1458-1467.

Pardo, M., and SuÁrez, G. (1995), Shape of the Subducted Rivera and Cocos Plates in Southern Mexico: Seismic and Tectonic Implications, J. Geophys. Res. 100, 12357-12373.

Schmitt, S. V., DeMets, C., Stock, J., Sánchez, O., MárquezAzúA, B., and Reyes, G. (2007), A Geodetic Study of the 2003 January 22 Tecomán, Colima, Mexico Earthquake, Geophys. J. Int. 169, 389-406.

Singh, S. K., Pacheco, J. F., Alcántara, L., Reyes, G., Ordaz, M., Iglesias, A., Alcocer., S M; Gutierrez, C.,Valdés, C., Kostoglodov, V., Reyes, C., Mikumo, T., QuaAs, R., and Anderson, J. G. (2003), A Preliminary Report on the Tecomán, Mexico Earthquake of 22 January $2003\left(M_{w} 7.4\right)$ and its Effects, Seismol. Res. Lett. 74(3), 279-289.

Waldhauser, F. (2001), hypoDD: A Program to Compute DoubleDifference Hypocenter Locations (hypoDD version 1.0-03/2001), U.S. Geol. Surv. Open File Rept. 01-113.

Waldhauser, F., and Ellsworth, W. L. (2000), A Double-Difference Earthquake Location Algorithm: Method and Application to the Northern Hayward Fault, California, Bull. Seism. Soc. Am. 90, 1353-1368.

Yagi, Y., Mikumo, T., Pachecho, J., and Reyes, G. (2004), Source Rupture Process of the Tecomán, Colima, Mexico Earthquake of 22 January 2003, Determined by Joint Inversion of Teleseismic Body-Wave and Near-Source Data, Bull. Seism. Soc. Am. 94, 1795-1807.

Yang, T., Grand, S. P., Wilson, D., Guzman-Speziale, M., GomezGonzalez, J. M., Domingues-Reyes, T., and Ni, J. (2009), Seismic Structure beneath the Rivera Subduction Zone from FiniteFrequency Seismic Tomography, J. Geophys. Res. 114, B01302, doi:10.1029/2008JB005830.

Zobin, V. M. and Pizano-Silva, J.A. (2007), Macroseismic Study of the $M_{w} 7.521$ January 2003 Colima, México, Across-Trench Earthquake, Bull. Seism. Soc. Am. 97, 1221-1232. 